\title{
Podmiotowy wymiar pracy a elastyczne formy zatrudnienia - uwagi na tle encykliki Jana Pawła II Laborem exercens
}

\section{Uwagi wstępne}

Założenia i wartości zawarte w encyklice Laborem exercens ${ }^{1}$ Jana Pawła II pozostają nadal aktualne. Rozwój nowych i elastycznych form zatrudnienia, odbiegających od tzw. klasycznego zatrudnienia w oparciu o umowę o pracę na czas nieokreślony w pełnym wymiarze czasu pracy, powoduje obniżanie standardów ochrony pracownika. Mimo upływu czasu polski ustawodawca nadal nie zdecydował o zakresie i ostatecznym kształcie regulacji w odniesieniu do elastycznych form zatrudnienia².

Od kilkunastu lat obserwujemy w Polsce rozwój elastycznych form zatrudnienia. Coraz mniejszą popularnością cieszy się „klasyczny stosunek pracy”, tzn. nawiązywany na podstawie bezterminowej umowy o pracę, wykonywanej

* Dr Anna Reda-Ciszewska, Katedra Prawa Pracy, Wydział Prawa i Administracji, Uniwersytet Kardynała Stefana Wyszyńskiego, 01-938 Warszawa, ul. Wóycickiego 1/3.

1 Jan Pawer II, Encyklika Laborem exercens, [w:] idem, Dzieła zebrane, t. 1: Encykliki, Kraków 2006, s. 107-143. Wszystkie cytaty opatrzone skrótem tytułu (LE) pochodzą z tego wydania.

${ }_{2}$ Mam na myśli to, że regulacje prawne odnoszące się obecnie do elastycznych form zatrudnienia nie są utrwalone w polskim porządku prawnych. Wystarczy podać przykład zatrudnienie na podstawie umowy o pracę na czas określony. Przepis art. $25^{1}$ k.p., i tak uznawany za nieskuteczne rozwiązanie ograniczające zatrudnienie na czas określony, był dotychczas dwukrotnie zawieszany (ostatnio częściowo, o czym będzie mowa w dalszej części tekstu). Inny przykład odnosi się do pracy tymczasowej, która została uregulowana w ustawie z dnia 9 lipca 2003 r. - pomimo zapowiedzi nowelizacji nie dokonano gruntownego przeglądu wskazanej regulacji. Nadal nie jest uregulowana kwestia zatrudnienia cywilnoprawnego, które zyskuje coraz większą popularność, pozbawiającego osoby wykonujące na jego podstawie pracę ochrony przewidzianej w Kodeksie pracy. 
w pełnym wymiarze czasu pracy w stałych godzinach i w określonym miejscu, z reguły w siedzibie pracodawcy ${ }^{3}$. Przyczyny tego nasilającego się zjawiska są bardzo zróżnicowane, ale można je ograniczyć, na potrzeby tego opracowania, do trzech kwestii: informatyzacji, internacjonalizacji gospodarki oraz indywidualizacji pracy. W skrócie rzecz ujmując, wzrasta znaczenie technologii informatycznych dla świata pracy, powstaje globalny rynek, a pracę dopasowuje się do życia człowieka, a nie odwrotnie ${ }^{4}$.

Już na wstępie należy wyjaśnić, że pojęcie elastycznych form zatrudnienia jest ujmowane na potrzeby tego opracowania bardzo szeroko, jednakże poniższe rozważania będą odnosić się jedynie do niektórych aspektów tzw. zatrudnienia elastycznego. W literaturze możemy spotkać bardzo różne określenia dotyczące zatrudnienia innego niż tzw. klasyczne. Można spotkać takie terminy, jak zatrudnienie nietypowe, atypowe, niestandardowe. Wśród tych form zatrudnienia wymienia się: kontraktowanie pracy, terminowe umowy o pracę, pracę tymczasową, samozatrudnienie, telepracę, pracę w domu, dzielenie się pracą, pracę na wezwanie i telefon ${ }^{5}$. Nie są to jednak wszystkie formy zatrudnienia nietypowego (elastycznego), ponieważ ich katalog pozostaje otwarty. Widocznym trendem są pogłębiające się różnice pomiędzy zatrudnionymi na podstawie umowy o pracę na czas nieokreślony a osobami zatrudnionymi w oparciu o elastyczne formy zatrudnienia i taka właśnie sytuacja - z punktu widzenia kwestii społecznych - jest niepokojąca.

Warto jednak zauważyć, że niektóre z nowych pojawiających się form zatrudnienia nietypowego zostały już objęte regulacją prawa pracy. Przykładem jest ustawa o zatrudnianiu pracowników tymczasowych ${ }^{6}$, a także przepisy o telepracy w kodeksie pracy ${ }^{7}$. Wraz z wprowadzeniem wskazanych unormowań, osobom świadczącym pracę w ramach tych form zatrudnienia została zagwarantowana w pewnym zakresie ochrona socjalna. Należy jednak od razu zaznaczyć, że poziom ochrony osób świadczących pracę tymczasową daleko odbiega od ochrony przewidzianej dla pracowników zatrudnionych w ramach umowy o pracę na czas nieokreślony.

3 Z. Кивот, Szczególne formy zatrudnienia i samozatrudnienia, [w:] Szczególne formy zatrudnienia, red. Z. Kubot, Wrocław 2000, s. 6 i n.; J. Wratny, Przemiany stosunku pracy w III RP, [w:] Współczesne problemy prawa pracy i ubezpieczeń społecznych, red. L. Florek, Ł. Pisarczyk, Warszawa 2011, s. 39.

${ }^{4}$ Szerzej na ten temat zob.: M. MoszyŃSkı, H. RITTER, Niezależni współpracownicy firmy jako wyzwanie dla zarządzania zasobami ludzkimi, „Praca i Zabezpieczenie Społeczne” 2003, s. 10.

5 M. Sewastianowicz, Przewidywane kierunki zmian nietypowych form zatrudnienia w Polsce, [w:] Elastyczny rynek pracy i bezpieczeństwo socjalne. Flexicurity po polsku?, red. M. Rymsza, Warszawa 2005, s. 110.

6 Ustawa z dnia 9 lipca 2003 r. o zatrudnianiu pracowników tymczasowych, Dz. U. nr 166, poz. 1608, ze zm.

7 Ustawa z dnia 24 sierpnia 2007 r. o zmianie ustawy - Kodeks pracy oraz niektórych innych ustaw, Dz. U. nr 181, poz. 1288. 
Trzeba podkreślić, że granica pomiędzy typowym i nietypowym zatrudnieniem nie jest wyraźna ${ }^{8}$. Wskazuje się, że granicą zatrudnienia nietypowego powinien być zakaz nieuzasadnionego zastępowania zatrudnienia tradycyjnego ${ }^{9}$. W doktrynie ocenia się, że z jednej strony włączenie uregulowania elastycznych form zatrudnienia do kodeksu pracy wzmocni ochronę osób wykonujących pracę na ich podstawie, z drugiej zaś zarówno pracę tymczasową, jak i telepracę można świadczyć w oparciu o cywilnoprawne formy zatrudnienia ${ }^{10}$.

Konsekwencją włączenia pracy tymczasowej i telepracy do prawa pracy jest także możliwość zakwalifikowania tych form zatrudnienia do zatrudnienia pracowniczego. Poza zatrudnieniem pracowniczym, tzn. objętym regulacją prawa pracy, wyróżniamy zatrudnienie o charakterze ustrojowym, administracyjnoprawnym, karnoprawnym oraz cywilnoprawnym ${ }^{11}$. Regulacją prawa pracy obejmuje się jedynie pracowników, tzn. osoby świadczące pracę zgodnie z art. 2 k.p. w oparciu o umowę o pracę, wybór, powołanie, mianowanie lub spółdzielczą umowę o pracę. Pozostałe rodzaje zatrudnienie pozostają, w zasadzie, poza prawem pracy.

Niektóre jednak regulacje szeroko ujmują pojęcie zatrudnienia, nie ograniczając się jedynie do zatrudnienia pracowniczego. W ustawie z dnia 20 kwietnia 2004 r. o promocji zatrudnienia i instytucjach rynku pracy ${ }^{12}$ pojęcie zatrudnienie zostało zdefiniowane i nie ogranicza się ono jedynie do stosunku pracy. Zgodnie z art. 2 ust. 1 pkt 43 ustawy zatrudnienie oznacza wykonywanie pracy na podstawie stosunku pracy, stosunku służbowego oraz umowy o pracę nakładczą. Natomiast w pkt. 11 definiuje się pojęcie innej pracy zarobkowej, przez którą należy rozumieć: wykonywanie pracy lub świadczenie usług na podstawie umów cywilnoprawnych, w tym umowy agencyjnej, umowy zlecenia, umowy o dzieło albo w okresie członkostwa w rolniczej spółdzielni produkcyjnej, spółdzielni kółek rolniczych lub spółdzielni usług rolniczych. Ustawa o promocji zatrudnienia odnosi się nie tylko do pracowniczych, lecz także do niepracowniczych podstaw zatrudnienia. Ustawodawca zauważa nowe i elastyczne formy zatrudnienia, odwołując się do nich w regulacjach prawnych. Natomiast powiatowe urzędy pracy mogą kierować bezrobotnych do odpowiedniej pracy. Zgodnie z art. 2 ust. 1 pkt. 16 ustawy o promocji zatrudnienia, odpowiednia praca oznacza zatrudnienie lub inną pracę zarobkową, które podlegają ubezpieczeniom społecznym i do wykonywania których bezrobotny ma wystarczające kwalifikacje lub doświadczenie zawodowe lub może je wykonywać po uprzednim szkoleniu albo przygotowaniu zawodowym dorosłych, a stan zdrowia pozwala mu na ich wykonywanie oraz łączny czas

8 Z. Кuвот, op. cit., s. 7.

9 L. FloReK, Granice liberalizacji prawa pracy, [w:] Granice liberalizacji prawa pracy. Problemy zabezpieczenia społecznego, red. E. Bielak, H. Lewandowski, Łódź 2003, s. 22.

${ }^{10}$ L. Florek, Kodyfikacyjne problemy prawa pracy, [w:] Problemy kodyfikacji prawa pracy. Wybrane zagadnienia zabezpieczenia społecznego, Referaty na XVI Zjazd Katedr oraz Zakładów Prawa Pracy i Ubezpieczeń Społecznych, red. A. Kubicka, Gdańsk 2007, s. 12.

11 Zob. Z. Кивот, ор. cit., s. 11.

12 Dz. U. nr 99, poz. 1001, ze zm. 
dojazdu do miejsca pracy i z powrotem środkami transportu zbiorowego nie przekracza 3 godzin, za wykonywanie których osiąga miesięczne wynagrodzenie brutto (w wysokości co najmniej minimalnego wynagrodzenia za pracę w przeliczeniu na pełny wymiar czasu pracy). W konsekwencji przyjąć należy, że odpowiednia praca to także wykonywanie pracy w ramach niepracowniczych, a w szczególności cywilnoprawnych podstaw zatrudnienia.

\section{Nauczanie Jana Pawła II o kwestiach społecznych}

Przed podjęciem bardziej szczegółowych rozważań na temat popularności zatrudnienia elastycznego i jego negatywnych aspektów należy sięgnąć do słów Jana Pawła II o pracy ludzkiej. U podstaw encykliki Laborem exercens leży stwierdzenie, że pracę można postrzegać albo jako towar, albo przez pryzmat jej wykonawcy - tj. człowieka. Praca ludzka stanowi klucz do całej kwestii społecznej, a także podstawowy wymiar bytowania człowieka na ziemi. Praca stanowi podstawę kształtowania życia rodzinnego, które jest naturalnym prawem i powołaniem człowieka. Papież podkreśla, że takie właśnie podmiotowe widzenie człowieka zawsze przeciwstawiane było różnym kierunkom myślenia materialistycznego i ekonomicznego, które traktuje pracę jako „towar”.

Podnosząc podmiotowy aspekt ludzkiej pracy, Jan Paweł II wskazuje, że stosunki społeczne nie mogą być postrzegane jedynie z punktu widzenia praw ekonomicznych. Papież ukazuje, jak ważna jest praca w życiu człowieka, a człowiek dla człowieka nie może być przecież towarem, ponieważ człowiek to podmiot pracy. Człowiek jako osoba pracuje, wykonuje czynności przynależące do procesu pracy, a one bez względu na swój charakter, mają służyć urzeczywistnianiu się jego człowieczeństwa, spełnianiu osobowego powołania, które jest mu dane właściwe z racji samego człowieczeństwa. Jan Paweł Il podkreśla, że pierwszą i podstawową wartością jest sam człowiek - podmiot pracy. Jeżeli prawdą jest, że człowiek jest przeznaczony i powołany do pracy, to praca jest dla człowieka. W ten sposób Jan Paweł II wskazuje na zasadę pierwszeństwa pracy przed kapitałem (zob. LE 6 i n.). Według Jana Pawła II, człowiek nie może być traktowany jako narzędzie produkcji, a powinien być traktowany jako sprawca i twórca. Właśnie błąd kapitalizmu pierwotnego, zdaniem Jana Pawła II, polega na potraktowaniu człowieka na równi z całym zespołem materialnych środków produkcji, jako narzędzia, a nie jako podmiotu i sprawcy.

Należy także wspomnieć, że w kolejnych encyklikach, chociaż nie były one poświęcone tematowi pracy ludzkiej, Jan Paweł II odnosił się również do kwestii społecznych. W encyklice Sollicitudo rei socialis (dalej SRS) papież podkreśla, że samo nagromadzenie dóbr i usług, nawet z korzyścią dla większości, nie wystarcza do urzeczywistnienia ludzkiego szczęścia. Można zatem przyjąć, 
iż rozwojowi gospodarczemu powinien towarzyszyć, na równi, rozwój społeczny. „Posiadanie” rzeczy i dóbr samo przez się nie doskonali człowieka, jeśli nie przyczynia się do dojrzewania i wzbogacenia jego „być” (SRS 28). Model rozwoju, który by nie szanował i nie popierał praw ludzkich, osobistych i społecznych, ekonomicznych i politycznych, łącznie z prawami narodów i ludów, nie byłby godny człowieka (SRS 33).

W encyklice Centesimus annus (dalej CA) Jan Paweł II pisze, że zysk nie jest jedynym wskaźnikiem dobrego funkcjonowania przedsiębiorstwa. Może się zdarzyć, że - mimo poprawnego rachunku ekonomicznego - ludzie, którzy stanowią najcenniejszy majątek przedsiębiorstwa, są poniżani i obraża się ich godność. Jest to moralnie niedopuszczalne i w dalszej perspektywie musi negatywnie odbić się na gospodarczej skuteczności przedsiębiorstwa. Celem zaś przedsiębiorstwa nie jest po prostu wytwarzanie zysku, ale samo jego istnienie jako wspólnoty ludzi, którzy na różny sposób zdążają do zaspokojenia swych podstawowych potrzeb i stanowią szczególną grupę służącą całemu społeczeństwu (CA 35). Papież podkreśla, że przedsiębiorstwa nie można uważać jedynie za „zrzeszenie kapitałów”. Jest ono równocześnie „zrzeszeniem osób”, w skład którego wchodzą w różny sposób i w różnych zakresach odpowiedzialności zarówno ci, którzy wnoszą konieczny do jego działalności kapitał, jak i ci, którzy w tę działalność wnoszą swą pracę (CA 43).

Z nauczania Jana Pawła II należy zatem wyciągnąć kilka wniosków ogólnych. Po pierwsze, Jan Paweł II nie rozróżnia podstaw zatrudnienia - odnosi się do pracy człowieka bez względu na podstawę jego zatrudnienia. W konsekwencji przyjąć trzeba, że każda praca zasługuje na ochronę. Po drugie, Jan Paweł II zauważa, że nie można pozostawić na marginesie kwestii społecznych, nie rozwiązując ich, a skupiać się jedynie na kwestiach ekonomicznych. Nauczanie Jana Pawła II uzasadnia przekonanie, że elastyczne formy zatrudnienia, które nie gwarantują odpowiedniej ochrony, prowadzą do uprzedmiotowienia pracownika. Traktują pracownika jak przedmiot, a nie podmiot pracy. O ile w czasach dzisiejszych nie można jednoznacznie negatywnie oceniać elastycznych form zatrudnienia, o tyle należy zauważyć, że również w przypadku tych form wypadałoby zagwarantować osobom wykonującym pracę odpowiednią ochronę. W tekście tym zostaną wskazane regulacje prawne, które nie przyznają odpowiedniej ochrony pracownikom zatrudnionym w ramach tzw. elastycznych form zatrudnienia. Oczywiście nie zostaną wyczerpująco zaprezentowane wszystkie funkcjonujące w praktyce tego typu przypadki, a jedynie wybrane zagadnienia, mające na celu zobrazowanie mniej korzystnej sytuacji pracowników nietypowych. Dla celów niniejszego opracowania wybrane zostały: praca tymczasowa, umowy o pracę na czas określony, zatrudnienie na podstawie umów cywilnoprawnych oraz samozatrudnienie. We wszystkich tych formach zatrudnienia nie gwarantuje się ochrony zatrudnienia na odpowiednim poziomie, choć warto podkreślić, że ustawodawca dostrzega nowe formy zatrudnienia i obejmuje je zakresem regulacji prawnej. 


\section{Praca tymczasowa}

Praca tymczasowa to dosyć kontrowersyjna, ale i zyskująca popularność w ostatnim czasie forma zatrudnienia. W przypadku pracy tymczasowej wskazuje się właśnie najczęściej, że pracownika traktuje się jak towar, ponieważ staje się on przedmiotem umowy pomiędzy formalnym pracodawcą a podmiotem użytkującym pracownika. Należy zgodzić się ze stanowiskiem, że już samo określenie „pracodawca użytkownik” jest uznawane za niezręczne i sugerujące właśnie uprzedmiotowienie pracownika tymczasowego ${ }^{13}$. Można także powołać się na model teoretyczny stworzony przez $\mathrm{H}$. Simon, według którego umowa o pracę nabiera coraz więcej cech umowy kupna-sprzedaży. Właśnie praca tymczasowa stanowi dowód istnienia takiej tendencji. Nie tylko praca tymczasowa, lecz także inne nietypowe umowy o zatrudnienie wykazują podobieństwo do umowy kupna-sprzedaży. Model ten nie wyklucza zastosowania umów bezterminowych, jego omówienie ma objaśnić wzrost zainteresowania elastycznymi formami zatrudnienia ${ }^{14}$.

Praca tymczasowa jest instytucją prawną wypełniającą pewną lukę na rynku, nie można jednak pozwolić na powszechne i swobodne wypożyczanie pracowników bez żadnych ograniczeń. Obecna ustawa o zatrudnianiu pracowników tymczasowych ${ }^{15}$ jest bardzo elastyczna, pozwala na stosowanie praktyk prowadzących do nadużywania pracy tymczasowej w praktyce.

W świetle polskiej regulacji, pracę tymczasową mogą stanowić jedynie zadania wskazane w ustawie. Zgodnie z art. 2 pkt 3, pracą tymczasową są zadania: (a) o charakterze sezonowym, okresowym, doraźnym; (b) takie, których terminowe wykonanie przez pracowników zatrudnionych przez pracodawcę użytkownika nie byłoby możliwe; (c) takie, których wykonanie należy do obowiązków nieobecnego pracownika zatrudnionego przez pracodawcę użytkownika. Pracownikowi tymczasowemu nie może być powierzone wykonywanie na rzecz pracodawcy użytkownika pracy: 1) szczególnie niebezpiecznej w rozumieniu przepisów wydanych na podstawie art. $237^{15}$ k.p.; 2) na stanowisku pracy, na którym jest zatrudniony pracownik pracodawcy użytkownika w okresie uczestniczenia tego pracownika w strajku; 3) na stanowisku pracy, na którym, w okresie ostatnich 3 miesięcy poprzedzających przewidywany termin rozpoczęcia wykonywania pracy tymczasowej przez pracownika tymczasowego był zatrudniony pracownik pracodawcy

13 W. Sanetra, Praca tymczasowa - zatrudnienie czy pośrednictwo pracy?, [w:] Z zagadnień współczesnego prawa pracy. Księga jubileuszowa Profesora Henryka Lewandowskiego, red. Z. Góral, Warszawa 2009, s. 327.

14 M. Moszyńskı, Nietypowe formy zatrudnienia w Republice Federalnej Niemiec, Toruń 2004, s. 54 .

15 Ustawa z dnia 9 lipca 2003 r. o zatrudnianiu pracowników tymczasowych, Dz. U. nr 166, poz. 1608, ze zm. 
użytkownika, z którym został rozwiązany stosunek pracy z przyczyn niedotyczących pracowników. Takie zawężające ujęcie pracy tymczasowej należy ocenić pozytywnie, ponieważ założeniem ustawy było uniemożliwienie sytuacji, w której pracownikiem tymczasowym jest się przez „całe życie”. Zgodnie z uzasadnieniem do projektu ustawy, praca tymczasowa miała ograniczyć wzrost bezrobocia i miała stanowić pomost pomiędzy bezrobociem a stałym zatrudnieniem. Z badań wynika, że nie więcej niż 5\% pracowników tymczasowych w latach 2004-2007 stawało się pracownikiem pracodawcy użytkownika po okresie wykonywania pracy tymczasowej ${ }^{16}$.

Przede wszystkim należy krytycznie zauważyć, że odstąpienie od określonych w ustawie przesłanek pracy tymczasowej nie wiąże się z żadnymi konsekwencjami. W praktyce często mamy do czynienia ze świadczeniem pracy „nietymczasowej” za pośrednictwem agencji pracy tymczasowej. W doktrynie wskazuje się, że takie właśnie wyraźne następstwa naruszenia przepisów prawa krajowego w innych państwach członkowskich zostały przewidziane. Jedną z możliwych i najbardziej dolegliwych konsekwencji dla pracodawcy użytkownika byłoby automatyczne nawiązanie stosunku pracy pomiędzy pracownikiem tymczasowym a pracodawcą użytkownikiem ${ }^{17}$.

Niestety, założenia ustawy o zatrudnianiu pracowników tymczasowych nie są realizowane w praktyce. W czasach kryzysu pracodawcy wymieniają pracowników stałych na tymczasowych albo proponują pracownikom stałym zatrudnienie na tym samym stanowisku pracy, ale za pośrednictwem agencji pracy tymczasowej. Z dniem 24 stycznia 2010 r. przestał obowiązywać art. 3 ustawy o zatrudnianiu pracowników tymczasowych ${ }^{18}$. Zgodnie z tym przepisem, pracodawcą użytkownikiem nie mógł być pracodawca, który w okresie ostatnich 6 miesięcy poprzedzających przewidywany termin rozpoczęcia wykonywania pracy tymczasowej przez pracownika tymczasowego wypowiedział pracownikom stosunki pracy lub rozwiązał te stosunki na mocy porozumienia stron z przyczyn niedotyczących pracowników, jeżeli liczba zwolnionych z tych przyczyn pracowników odpowiada liczbie określonej w art. 1 ustawy z dnia 13 marca 2003 r. o szczególnych zasadach rozwiązywania z pracownikami stosunków pracy z przyczyn niedotyczących pracowników ${ }^{19}$. Pracodawca użytkownik składał agencji pracy

16 Za: A. PATULSKI, Koncepcja flexicurity a nietypowe formy zatrudnienia, czyli jak ograniczyć segmentację polskiego rynku pracy, [w:] Stosunki zatrudnienia w dziesięcioleciu społecznej gospodarki rynkowej, Księga pamiątkowa z okazji jubileuszu 40-lecia pracy naukowej Profesor Barbary Wagner, red. A. Sobczyk, Warszawa 2010, s. 364.

17 A. SoвczYk, Zatrudnienie tymczasowe. Komentarz, Warszawa 2009, s. 24. Autor postuluje wprowadzenie m.in. kategorycznych uregulowań karnych w stosunku do agencji oraz pracodawców użytkowników, a także konsekwencji w sferze cywilnoprawnej np. prawa do odprawy z tytułu ustawy o zwolnieniach grupowych.

18 Uchylony ustawą z dnia 23 października 2009 r. o zmianie ustawy o zatrudnianiu pracowników tymczasowych, Dz. U. nr 221, poz. 1737.

19 Dz. U. nr 90, poz. 844, ze zm. 
tymczasowej pisemne oświadczenie w tej sprawie. Przepis ten miał na celu zapobieżenie praktyce wymiany pracowników stałych na pracowników tymczasowych. Należy powyższą zmianę ocenić negatywnie. Wprawdzie w ustawie o zatrudnianiu pracowników tymczasowych pozostał art. 8 pkt 3, który nie pozwala na zatrudnienie pracownika tymczasowego na stanowisku, na którym w okresie ostatnich 3 miesięcy poprzedzających przewidywany termin rozpoczęcia wykonywania pracy tymczasowej przez pracownika tymczasowego był zatrudniony pracownik pracodawcy użytkownika, z którym został rozwiązany stosunek pracy z przyczyn niedotyczących pracowników. Jednak regulacja w obecnym stanie wręcz zachęca do wymiany stałych pracowników na pracowników tymczasowych. Niestety, ograniczenia przewidziane w zakresie dopuszczalności stosowania pracy tymczasowej należy uznać za nieskuteczne.

Innym przykładem nieskutecznego rozwiązania ustawy o zatrudnianiu pracowników tymczasowych jest przepis przewidujący ograniczenia czasowe w związku z wykonywaniem pracy tymczasowej. Na podstawie art. 20 ustawy w okresie obejmującym 36 kolejnych miesięcy agencja pracy tymczasowej zatrudniająca pracownika tymczasowego może skierować go do wykonywania pracy tymczasowej na rzecz jednego pracodawcy użytkownika przez okres nieprzekraczający łącznie 18 miesięcy. Jeżeli pracownik tymczasowy wykonuje w sposób ciągły na rzecz danego pracodawcy użytkownika pracę tymczasową obejmującą zadania, których wykonanie należy do obowiązków nieobecnego pracownika zatrudnionego przez tego pracodawcę użytkownika, okres wykonywania pracy tymczasowej nie może przekroczyć 36 miesięcy. Przepis ten budzi poważne wątpliwości, ponieważ nie jest jasne, czy obejmuje pracownika tymczasowego kierowanego do tego samego pracodawcy użytkownika po maksymalnym okresie wykonywania pracy tymczasowej, ale przez inną agencję pracy tymczasowej. Moim zdaniem należy przyłączyć się do prezentowanego w literaturze poglądu, że ograniczenie powyższe odnosi się także do pracodawcy użytkownika, w przeciwnym razie interpretacja będzie niezgodna $z$ celem ustawy ${ }^{20}$. Wątpliwości tej ustawodawca nie rozwiał, wydłużając okres świadczenia pracy tymczasowej z 12 do 18 miesięcy ${ }^{21}$.

Podsumowując należy zauważyć, że praca tymczasowa jako kontrowersyjna forma świadczenia pracy ma na celu wyeliminowanie pracowniczej więzi prawnej pomiędzy pracodawcą a pracownikiem - a tworzy więź, której charakter nie jest doprecyzowany. Na takiej właśnie trójstronnej konstrukcji zatrudnienia najbardziej traci pracownik tymczasowy.

20 D. MAкоwskı, Praca tymczasowa jako nietypowa forma zatrudnienia, Warszawa 2006, s. 104; A. SoвczYk, op. cit., s. 102.

${ }^{21}$ Nowy, dłuższy okres świadczenia pracy tymczasowej obowiązuje od dnia 24 stycznia 2010 r., Dz. U. 2009, nr 221, poz. 1737. 


\section{Umowy o pracę na czas określony}

Niezwykle istotnym problemem w Polsce jest wzrastająca liczba zawieranych umów o pracę na czas określony ${ }^{22}$. Niestety, ustawodawca jest dosyć nieporadny we wprowadzaniu skutecznych ograniczeń stosowania umów o pracę na czas określony, mimo że obowiązek wprowadzenia takich właśnie rozwiązań podyktowany jest dyrektywą 99/70/WE ${ }^{23}$. Zatrudnienie na czas określony nie sprzyja stabilizacji. Z badań wynika, że dopuszczenie zawierania umów terminowych nie tylko nie wpływa na obniżenie bezrobocia, lecz także może spowodować jego wzrost i obniżenie zamożności niektórych grup społecznych ${ }^{24}$.

Polska, mimo że związana standardami unijnymi, od lat nie ma skutecznego rozwiązania prawnego w odniesieniu do zawierania umów terminowych. Dyrektywa 99/70/WE przewiduje zgodnie z klauzulą 5, że państwa członkowskie - w celu zapobiegania nadużyciom wynikającym z wykorzystywania kolejnych umów o pracę lub stosunków pracy zawieranych na czas określony - po przeprowadzeniu konsultacji z partnerami społecznymi, zgodnie z ustawodawstwem krajowym, układami zbiorowymi i praktyką, wprowadzają (o ile nie istnieją równoważne rozwiązania prawne, zmierzające do zapobiegania nadużyciom) w sposób uwzględniający potrzeby poszczególnych gałęzi lub grup pracowników, jeden lub więcej spośród następujących środków: (a) obiektywne powody, uzasadniające odnowienie takich umów lub stosunków pracy; (b) maksymalną łączną długość kolejnych umów o pracę lub stosunków pracy na czas określony; (c) liczbę odnowień takich umów lub stosunków. Kraje unijne, po konsultacji z organizacjami związkowymi i organizacjami pracodawców, ustalają, o ile to właściwe, na jakich warunkach umowy zawarte na czas określony lub stosunki pracy (a) będą uważane za „kolejne”; (b) będą uważane za umowy o pracę lub stosunki pracy zawarte na czas nieokreślony.

Obecnie w Polsce funkcjonuje art. $25^{1}$ k.p. ograniczający zatrudnienie terminowe, natomiast nie obowiązuje już art. 13 ustawy antykryzysowej, który dotyczył tylko pracodawców posiadających jednocześnie status przedsiębiorcy i ograniczał stosowanie umów terminowych ${ }^{25}$. Takie podwójne uregulowanie kwestii zatrudnienia w oparciu o umowy o pracę na czas określony było krytycznie oceniane z punktu widzenia zgodności z art. 32 Konstytucji R.P. ${ }^{26}$ Ustawa antykryzysowa

22 Pracownicy terminowi stanowią w Polsce blisko 30\% ogółu pracowników. Zob. np. A. PATULSKI, op. cit., s. 362, przyp. 16.

${ }^{23}$ Dyrektywa Rady 99/70/WE z dnia 28 czerwca 1999 r. dotycząca Porozumienia ramowego w sprawie pracy na czas określony, zawartego przez Europejską Unię Konfederacji Przemysłowych i Pracodawców (UNICE), Europejskie Centrum Przedsiębiorstw Publicznych (CEEP) oraz Europejską Konfederację Związków Zawodowych (ETUC), Dz. U. L 175, 10.07.1999, s. 43-48.

24 M. SKĄPSKI, Ochronna funkcja prawa pracy w gospodarce rynkowej, Kraków 2006, s. 265.

25 Ustawa z dnia 1 lipca 2009 r. o łagodzeniu skutków kryzysu ekonomicznego dla pracowników i przedsiębiorców, Dz. U. nr 125, poz.1035, ze zm., dalej ustawa antykryzysowa.

${ }^{26}$ K. W. BARAN, Umowa o pracę na czas określony w ustawie o łagodzeniu skutków kryzysu ekonomicznego dla pracowników i przedsiębiorców, „Monitor Prawa Pracy” 2009, nr 9, s. 455. 
przestała obowiązywać z końcem 2011 r., a nowa nie przewiduje już uregulowania w zakresie umów terminowych ${ }^{27}$.

Zgodnie $z$ art. $25^{1}$ k.p., zawarcie kolejnej umowy o pracę na czas określony jest równoznaczne w skutkach prawnych z zawarciem umowy o pracę na czas nieokreślony, jeżeli poprzednio strony dwukrotnie zawarły umowę o pracę na czas określony na następujące po sobie okresy, o ile przerwa między rozwiązaniem poprzedniej a nawiązaniem kolejnej umowy o pracę nie przekroczyła 1 miesiąca. Warto jednak wyraźnie zaznaczyć, że zasada ta odnosi się jedynie do umów o pracę na czas określony, ale nie do wszystkich, ponieważ w $\S 3$ wyraźnie zostało wyłączone stosowanie tego przepisu do umów o pracę zawartych w celu zastępstwa pracownika w czasie jego usprawiedliwionej nieobecności w pracy oraz zawartych w celu wykonywania pracy o charakterze dorywczym lub sezonowym albo zadań realizowanych cyklicznie. Z mocy art. 21 ustawy o zatrudnianiu pracowników tymczasowych nie stosuje się tego przepisu do pracowników tymczasowych. W związku z tym, że art. $25^{1}$ k.p. nie obejmuje swoim zakresem wszystkich umów terminowych, uznawany jest za niezgodny z dyrektywą 99/70/WE ${ }^{28}$.

Zasada $z$ art. $25^{1}$ k.p. od dawna jest uznawana za nieskuteczną. Dla pracodawców przepis powyższy stał się impulsem do wyszukiwania nowych sposobów jego obchodzenia. Dlatego też w piśmiennictwie wskazywane są inne adekwatne ograniczenia, które można by wykorzystać z uwagi na nadużywanie przez pracodawców umowy o pracę na czas określony. W grę wchodzi ewentualne odstąpienie od dopuszczalności wypowiadania umów na czas określony albo wprowadzenie roszczenia o przywrócenie do pracy $w$ razie naruszenia przepisów o wypowiedze$n^{n^{29}}{ }^{29}$. Natomiast $w$ projekcie kodeksu pracy zaproponowano rezygnację $z$ dotychczasowej treści art. $25^{1}$ k.p. oraz wprowadzenie maksymalnego okresu wykonywania pracy na podstawie umowy o pracę na czas określony. Według projektowanego art. 64, łączny okres zatrudnienia u danego pracodawcy na podstawie kolejnych umów o pracę na czas określony nie mógłby przekraczać trzech lat ${ }^{30}$.

Tymczasem właśnie ograniczenia czasu trwania umowy o pracę na czas określony zostały przyjęte w nieobowiązującej już ustawie antykryzysowej. Zgodnie z jej art. 13, okres zatrudnienia na podstawie umowy o pracę na czas określony, a także łączny okres zatrudnienia na podstawie kolejnych umów o pracę na czas określony między tymi samymi stronami stosunku pracy, nie mógł przekraczać

27 Ustawa z dnia 11 października 2013 r. o szczególnych rozwiązaniach związanych z ochroną miejsc pracy, Dz. U. 2013, poz. 1291.

${ }^{28}$ L. Mitrus, Wpływ regulacji wspólnotowych na polskie prawo pracy, Kraków 2006, s. 219; A. REDA, Umowa o pracę na zastępstwo $w$ kontekście ograniczeń w zawieraniu terminowych umów o prace według unijnej dyrektywy, „Praca i Zabezpieczenie Społeczne” 2013, nr 6, s. 21 i n.

${ }_{29}$ B. WAGner, O swobodzie umowy o pracę raz jeszcze, [w:] Prawo pracy a wyzwania XXI w. Księga jubileuszowa Profesora Tadeusza Zielińskiego, Warszawa 2002, s. 369.

${ }_{30}$ Kodeks pracy (projekt), kwiecień 2007, s. 23; tekst projektu (stan na dzień 8.08.2011) można odnaleźć na stronie http://www.mpips.gov.pl/gfx/mpips/userfiles/File/Departament\%20Prawa\%20Pracy/kodeksy\%20pracy/ KP_04.08..pdf [dostęp: 5.05.2013]. Jednak projekt ten nie stanie się prawdopodobnie prawem obowiązującym. 
24 miesięcy, przy czym za kolejną umowę na czas określony uważano umowę zawartą przed upływem 3 miesięcy od rozwiązania lub wygaśnięcia poprzedniej umowy zawartej na czas określony. Unormowanie powyższe mogłoby stanowić skuteczniejsze rozwiązanie niż przewidziana w kodeksie pracy reguła.

Na marginesie należy jedynie wspomnieć, że w Polsce problemem jest także zawieranie długoletnich umów o pracę na czas określony. Sąd Najwyższy zdecydowanie wypowiada się negatywnie na temat długoletnich umów terminowych. W jednym z pierwszych wyroków dotyczącym długoletnich umów o pracę na czas określony stwierdzono, że zawarcie długoterminowej umowy o pracę na czas określony (9 lat) z dopuszczalnością jej wcześniejszego rozwiązania za dwutygodniowym wypowiedzeniem może być kwalifikowane jako obejście przepisów prawa pracy, ich społeczno-gospodarczego przeznaczenia lub zasad współżycia społecznego (art. 58 § 1 i 2 k.c. w związku z art. 300 k.p.) ${ }^{31}$. W innym z wyroków Sąd Najwyższy stwierdził, że niedopuszczalne jest zawarcie wieloletniej umowy o pracę na czas określony z klauzulą wcześniejszego jej rozwiązania za dwutygodniowym wypowiedzeniem, chyba że co innego wynika z przepisów prawa pracy albo z charakteru umowy dotyczącej wykonywania zadań oznaczonych w czasie albo gdy z innych przyczyn nie narusza to usprawiedliwionego i zgodnego interesu obu stron stosunku pracy. Jeżeli zawarcie umowy o pracę na czas określony było niedopuszczalne, stosunek pracy podlega przepisom prawa pracy o umowie na czas nieokreślony ${ }^{32}$.

Mimo jednak braku skutecznego ograniczenia w zakresie zawierania umów o pracę na czas określony i negatywnych wypowiedzi Sądu Najwyższego na temat długoletnich umów terminowych, ustawodawca nadal projektuje rozwiązania prawne, które podważają stabilizację zatrudnienia i funkcję ochronną prawa pracy. Mam tu na myśli zaproponowane ostatnio rozwiązanie w odniesieniu do pracowników artystycznych. Projekt ustawy o zmianie ustawy o organizowaniu i prowadzeniu działalności kulturalnej oraz niektórych innych ustaw ${ }^{33}$ przewidywał, że podstawą zatrudnienia pracownika artystycznego (w szczególności zatrudnionego na stanowiskach: aktora, śpiewaka, tancerza lub muzyka) byłaby umowa o pracę na czas określony, obejmujący od jednego do pięciu sezonów artystycznych, przy czym sezon artystyczny rozpoczynałby się 1 września, a kończył 31 sierpnia następnego roku. Natomiast na jego wniosek podstawą zatrudnienia pracownika artystycznego byłaby umowa o pracę na czas nieokreślony, ale dopiero po przepracowaniu łącznie w instytucjach artystycznych 15 sezonów artystycznych. Rozwiązanie powyższe nie stanie się jednak obowiązujące, ponieważ zostało odrzucone przez Sejm 1 lipca 2011 r. po protestach środowiska artystycznego oraz związków zawodowych.

${ }^{31}$ Wyrok Sądu Najwyższego z dnia 7 września 2005 r., II PK 294/04, Orzecznictwo Sądu Najwyższego Zbiór Urzędowy Izba Pracy, Ubezpieczeń Społecznych i Spraw Publicznych 2006/13-14/207.

${ }^{32}$ Wyrok Sądu Najwyższego z dnia 25 października 2007 r., II PK 49/07, OSNP 2008, nr 21-22, poz. 317.

${ }^{33}$ Druk sejmowy $\mathrm{nr} 3786$. 


\section{Problem samozatrudnienia i umów cywilnoprawnych}

Bardzo powszechne w Polsce w ostatnim czasie staje się samozatrudnienie. Jest ono uznawane jest za przejaw elastyczności funkcjonalnej, tj. zmiany organizacji i stosunków pracy na rynkach pracy oraz upowszechniania się praktyki kontraktowania pracy ${ }^{34}$. Osoby samozatrudnione nie mają jednak zagwarantowanych w polskim prawie podstawowych uprawnień, tj. prawa do wypoczynku, ochrony macierzyństwa czy też prawa zrzeszania się w związkach zawodowych. Natomiast $z$ uprawnień określonych w ustawie o promocji zatrudnienia i instytucjach rynku pracy (art. 43) ${ }^{35}$ może korzystać jedynie osoba będąca w okresie wypowiedzenia stosunku pracy lub stosunku służbowego z przyczyn dotyczących zakładu pracy. $Z$ wielu instrumentów rynku pracy mogą korzystać jedynie pracownicy i pracodawcy. Poza kręgiem osób uprawnionych pozostają osoby zatrudnione na podstawie umów cywilnoprawnych ${ }^{36}$.

W piśmiennictwie wskazuje się, że elastyczność w zakresie zatrudniania nie może łączyć się z brakiem jakiejkolwiek ochrony dla zatrudnionych niepracowni$\mathrm{CzO}^{37}$. W projekcie nowego kodeksu pracy zostało zawarte uregulowanie w odniesieniu do osób zatrudnionych na podstawie umowy innej niż umowa o pracę, wykonujących osobiście na rzecz jednego zatrudniającego pracę o charakterze ciągłym lub powtarzającym się za wynagrodzeniem przekraczającym połowę wynagrodzenia minimalnego ustalonego na podstawie przepisów odrębnych (art. $462 \S 1$ i następne projektu kodeksu pracy). Projektowana regulacja wprowadziła pojęcie zatrudnienia niepracowniczego i przewidywała, że osoby zatrudnione $w$ ten sposób mogłyby zostać objęte układem zbiorowym pracy oraz ustanawianymi na podstawie ustawy porozumieniami zbiorowymi, regulaminami i statutami.

Do podstawowych elementów ochrony gwarantowanej przez projektowany kodeks osobom wykonującym zatrudnienie niepracownicze należą: objęcie ich właściwością sądów pracy w zakresie ich uprawnień określonych w kodeksie, zakaz dyskryminacji podczas zatrudniania, zaliczanie stażu pracy w charakterze wykonawcy do stażu pracowniczego. Jeśli chodzi o szczegółowe regulacje ochronne, dotyczące zatrudnienia niepracowniczego, to należy wskazać: pisemną formę umowy, zapewnienie okresów wypowiedzenia, ochronę przed niezwłocznym rozwiązaniem umowy, ograniczenie możliwości wypowiedzenia umowy i rozwiązania jej bez wypowiedzenia z kobietą w ciąży i w okresie 8 tygodni po porodzie, urlop

\footnotetext{
${ }^{34}$ M. RYmsza, W poszukiwaniu równowagi między elastycznością rynku pracy i bezpieczeństwem socjalnym. Polska w drodze do flexicurity, [w:] Elastyczny rynek pracy..., s. 28.

35 Dz. U. nr 99, poz. 1001, ze zm.

${ }^{36}$ A. M. ŚwIĄTKowskı, M. WuJczYK, Między elastycznością zatrudnienia a stabilnością socjalną. Idea flexsecurity na początku XXI w., „Praca i Zabezpieczenie Społeczne” 2011, nr 5, s. 9. Chociaż osoba samozatrudniona po zakończeniu prowadzenia działalności gospodarczej może zarejestrować się jako bezrobotny.

37 Zob. L. Florek, Liberalizacji prawa pracy i jej granice, „Państwo i Prawo” 2003, nr 12, s. 10.
} 
macierzyński, ograniczona ochrona wynagrodzenia, bezpłatny urlop wypoczynkowy na żądanie. Powyższy zakres uprawnień oceniany był jako uprawnienia minimalne, które powinny zostać wykonawcom zagwarantowane. Regulacja w tym kształcie nie miała na celu zrównania wykonawców z pracownikami ${ }^{38}$. Jednak projektowane w tym kształcie rozwiązania prawdopodobnie nie staną się obowiązującymi, a osoby samozatrudnione i wykonujące pracę na podstawie umów cywilnoprawnych nadal będą pozbawione regulacji ochronnych.

Wprowadzenie regulacji ochronnych w odniesieniu do samozatrudnionych będzie jednak zadaniem trudnym z uwagi na niejednolitość tej kategorii podmiotów. Trzeba podkreślić, że do kręgu osób samozatrudnionych będą należeć zarówno ci, którzy nie zatrudniają ani jednego pracownika, jak i ci, którzy zatrudniają niewielką liczbę osób, a nawet pracowników. Wprowadzenie ewentualnych uregulowań ochronnych powinno zostać poprzedzone skonstruowaniem definicji samozatrudnienia w prawie polskim. Objęcie samozatrudnionych ochronnymi regulacjami prawa pracy jest jednak możliwe, wystarczy wskazać regulacje prawne niektórych państw członkowskich ${ }^{39}$. Dobrym rozwiązaniem byłoby przyjęcie odpowiedniego wariantu na szczeblu unijnym tak, aby ujednolicić uregulowania w prawie krajowym w podobnym duchu. Istnieje jednak ogólna tendencja do obejmowania samozatrudnienia regulacjami ochronnymi prawa pracy ${ }^{40}$.

\section{Podsumowanie}

Obecnie uelastycznienie zatrudnienia uznawane jest za jeden z podstawowych wyznaczników funkcjonowania przedsiębiorstwa na rynku. Nie można go jednak traktować jako gotowej recepty pozwalającej pracodawcom osiągnąć sukces. Należy pamiętać, że każde przedsiębiorstwo jest także układem społecznym ${ }^{41}$. Elastyczne rozwiązania dotyczące zatrudnienia nie sprzyjają poczuciu bezpieczeństwa człowieka w miejscu pracy, łączą się także z konsekwencjami w postaci spadku zaangażowania i lojalności pracowników. Można nawet stwierdzić, iż poszerza się grupa tzw. pracowników cynicznych, którzy mają poczucie wykorzystania, ale wobec braku stabilizacji zatrudnienia nie angażują się w obowiązki pracownicze ${ }^{42}$.

38 Zob. J. Wratny, Między pracą a kapitałem, „Dialog, Pismo Dialogu Społecznego” 2008, nr 2.

${ }^{39} \mathrm{~W}$ prawie niemieckim osoby samozatrudnione, których sytuacja jest podoba do pracowników mają dostęp do wybranych instytucji ochronnych prawa pracy. Zob. M. SKĄPSKı, op. cit., s. 413. Autor powołuje się na P. L. DAvies, Zatrudnienie pracownicze $i$ samo zatrudnienie $w$ świetle common law, [w:] Referaty na VI Kongres Prawa Pracy i Zabezpieczenia Społecznego, Warszawa 1999, s. 198.

40 A. PERULLI, Economically dependent / quasi-subordinate (parasubordinate) employment: legal, social and economic aspects, Brussels 2003, s. 116.

41 A. Cierniak-Emerych, A. Pietroń-PYszczek, Elastyczności w obszarze zatrudnienia - optyka pracodawcy, „Zarządzanie Zasobami Ludzkimi” 2008, nr 5, s. 29-30, 33, 35.

42 M. ŁACIAK, Cynizm w organizacji, „Zarządzanie Zasobami Ludzkimi” 2010, nr 2, s. 31 
Elastyczne formy zatrudnienia i ich nadmierne wykorzystanie może prowadzić do negatywnych skutków społecznych w dalszej perspektywie. Wystarczy podać przykład osób samozatrudnionych, które opłacają dzisiaj najniższe składki na ubezpieczenie społeczne, wobec czego po osiągnięciu wieku emerytalnego uzyskają tak niskie świadczenia, że konieczne będzie wsparcie tej grupy z pomocy społecznej. W związku z poważnymi, choć odległymi w czasie konsekwencjami nie można się godzić na dalsze osłabienie funkcji ochronnej prawa pracy. Brak bezpieczeństwa w ramach elastycznych form zatrudnienia prowadzi do traktowania pracownika jako przedmiotu i jest zaprzeczeniem podmiotowego wymiaru pracy ludzkiej. Warto w tym kontekście nawiązać do Deklaracji filadelfijskiej, sformułowanej przez Międzynarodową Organizację Pracy, w której stwierdzono, że praca nie jest towarem ${ }^{43}$.

Stawiając pytanie o zakres ochrony zatrudnionych w ramach elastycznych form zatrudnienia, należy stwierdzić, że nie powinno dochodzić do pogłębiania się różnic pomiędzy pracownikami zatrudnionymi na podstawie umowy o pracę na czas nieokreślony a pracownikami nietypowymi (np. tymczasowymi, terminowymi) oraz osobami zatrudnionymi niepracowniczo. Pojawiają się różne propozycje, a w szczególności - aby pracownikom nietypowym zapewnić taką samą ochronę, jak ta, która przysługuje zatrudnionym w systemie tradycyjnym ${ }^{44}$. Niestety, w okresie kryzysu ekonomicznego nie będzie to możliwe, ponieważ ustawa antykryzysowa miała na celu uelastycznienie niektórych rozwiązań prawa pracy. Należy jednak zgodzić się ze stwierdzeniem, że osłabienie ochrony nie powinno następować w momencie, kiedy najsłabsi najbardziej jej potrzebują ${ }^{45}$. Na pewno wprowadzenie rozwiązań prawnych, gwarantujących odpowiednią ochronę wszystkim podmiotom wykonującym pracę nie jest łatwe, ale takiego właśnie rozwiązania, w kontekście nauczania Jana Pawła II, należałoby oczekiwać $^{46}$. Pamiętać trzeba, że praca to „klucz do całej kwestii społecznej”.

43 Deklaracja filadelfijska z 10 maja 1944 r., [w:] A. M. ŚwiĄTKowskı, Międzynarodowe prawo pracy, t. 1: Międzynarodowe publiczne prawo pracy, vol. 1, Warszawa 2008, s. 149.

44 A. Kosut, Glosa do wyroku Sądu Najwyższego II PK 49/07, OSNP 2008, nr 21-22, poz. 317, Orzecznictwo Sądów Polskich 2009/7-8/76, s. 530.

45 J. Stelina, Prawo pracy a kryzys gospodarczy, „Państwo i Prawo” 2010, nr 3, s. 19.

46 Zob. I. BorUtA, W sprawie przyszłości prawa pracy, „Praca i Zabezpieczenie Społeczne” 2005, nr 4, s. 7. 